\title{
EFFECT OF SONICATION APPLIED DURING PRODUCTION OF CARBON FIBER/EPOXY RESIN COMPOSITES EVALUATED BY DIFFERENTIAL SCANNING CALORIMETRY AND THERMO-GRAVIMETRIC ANALYSIS
}

\author{
Gordana Bogoeva-Gaceva ${ }^{*}$, Dimko Dimeski ${ }^{2}$, Niko Heraković ${ }^{3}$

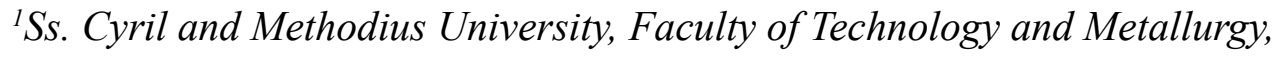 \\ Skopje, Republic of Macedonia \\ ${ }^{2}$ Goce Delčev University, Štip, Republic of Macedonia \\ ${ }^{3}$ University in Ljubljana, Faculty of Mechanical Engineering, Ljubljana, Slovenia \\ gordana@tmf.ukim.edu.mk
}

\begin{abstract}
The influence of ultrasonic treatment, applied during the impregnation of carbon fiber bundle by epoxy resin system, on thermal behavior of carbon fiber/epoxy resin composites in the course of crosslinknetwork formation has been analyzed by differential scanning calorimetry (DSC). It was previously shown [1] that this treatment has resulted in drastically increased interlaminar shear strength (ILSS) of the bulk composites, produced by hot pressing. The enhanced ILSS was attributed to the formation of more homogeneous and dense network, as revealed by epoxy consumption rate and increased $T \mathrm{~g}$. In this paper, DSC analysis is applied to further investigate peculiarities of carbon fiber/epoxy systems, exposed to ultrasonic treatment, during isothermal and non-isothermal curing and post-curing. The acceleration of the curing reaction as a consequence of sonication effects was found for all fiber/polymer systems, regardless the surface chemistry of the fibers. The stronger interfacial bond in epoxy sized carbon fiber composites, favored by ultrasound treatment, has also generated differences in thermal behavior of the composites during their degradation followed by TGA/DTG.
\end{abstract}

Key words: carbon fibers; epoxy composites; ultrasound treatment; DSC, thermal degradation

\section{ЕФЕКТ НА УЛТРАЗВУЧНАТА ОБРАБОТКА ПРИ ПРОИЗВОДСТВО НА ЕПОКСИДНИ КОМПОЗИТИ СО ЈАГЛЕРОДНИ ВЛАКНА ОЦЕНЕТ СО МЕТОДИТЕ НА ДИФЕРЕНЦИЈАЛНА СКЕНИРАЧКА КАЛОРИМЕТРИЈА И ТЕРМОГРАВИМЕТРИСКА АНАЛИЗА}

\footnotetext{
Испитувано е влијанието на ултразвучниот третман, применет во фазата на импрегнација на јаглеродни влакна со епоксидна смола, врз текот на процесот на вмрежување на епокси-композитите, следен co DSC. Претходно беше покажано [1] дека ултразвучниот третман применет во фазата на импрегнација на јаглеродните влакна со епоксидна смола резултира во драстчно зголемување на меѓуслојната јачина на смолкнување (ILSS) на композитите добиени со пресување. Формирањето на вмрежена структура беше следено на моделни композити кои содржат нетретирани, оксидирани и епокси-третирани влакна со помош на FTIR-микроскопија и DSC-анализа. Зголемената ILSS беше поврзана со создадената похомогена структура со поголема густина, како што покажаа кинетичките испитувања и зголемената $\mathrm{Tg}$. Во овој труд, DSC е применета за натамошно истражување на особеностите на јаглеродно епоксидните системи, подложени на ултразвучен третман, и тоа во текот на изотермно и неизотермно вмрежување, како и по процес на дополнително пост-вмрежување.
} 
Испитувана е и термичката деградација на композитите произведени во процес со примена на ултразвук. Добиените резултати се споредени со оние кај композитите произведени во конвенционален процес на пресување.

Клучни зборови: јаглеродни влакна; епоксидни композити; ултразвучен третман; DSC; термичка деградација

\section{INTRODUCTION}

Epoxy resin based composites are widely used as laminates for engineering components, ballistic, aerospace, etc., because of their excellent mechanical and thermal properties and usually good reinforcing fibers-to-matrix bonding strength.

Power ultrasound is widely applied in numerous industrial processes, since it is well known that it can enhance a variety of chemical and physical processes mainly due to the ultrasonic cavitation effect in a liquid medium $[2,3]$. Recently, it was applied to enhance thermo-mechanical properties of epoxy-matrix nanocomposites reinforced with randomly dispersed carboxylic-functionalized single-walled carbon nanotubes [4]. The use of ultrasonic energy, also represents a new approach for general bonding applications and especially repair with RT curing adhesive systems [5, 6]. Relatively unknown is the possibility to apply ultrasonic treatment for homogenous and heterogeneous chemical synthesis and especially to influence interface reactions [5-8].

In our previous paper [1] we investigated the influence of ultrasonic treatment, applied to the carbon fiber bundle after impregnation by epoxy resin, on mechanical properties of the composites reinforced with differently treated/ sized carbon fibers. The effect of ultrasonic treatment resulted in achieving higher epoxy crosslinking degree, especially at the fiber/matrix interface region. Its influence was mostly pronounced in epoxy-sized carbon fiber reinforced composites, as compared to oxidized and untreated ones. As a result of the creation of an interface region with different rheological and mechanical properties, differences in the response to shear forces of the bulk compos- ites produced via conventional and ultrasound assisted process were found. The enhanced interlaminar shear strength (ILSS) (up to 15\%) of the composites treated by ultrasound was attributed to the formation of more homogeneous and dense network, as revealed by FTIR and DSC analysis.

In this paper we report the results of thermal behavior of carbon fiber/epoxy resin composites produced via ultrasound-assisted process analyzed by DSC and TGA/DTG. The results of thermal degradation of the composites produced via ultrasound-assisted process are compared to those produced via conventional hot pressing procedure. Additionally, DSC experiments after isothermal curing of model fiber/resin composites were conducted to determine the changes of the epoxy network density with respect to ultrasound treatment performed on carbon fibers with different surface chemistry.

\section{EXPERIMENTAL}

Carbon fibers with a nominal diameter of $7 \mu \mathrm{m}$ (Teijin Fibers Ltd.), oxidized (CFO), epoxy sized (CFE) and untreated unsized (CF) have been used to investigate the influence of ultrasound treatment on thermal properties of epoxy resin composites. To exclude the effect of fiber surface morphology on interface sensitive properties, $\mathrm{CFO}$ fibers without any pronounced roughening of the surface within the resolution range of the SEM $(0.1 \mu \mathrm{m})$ were chosen for the production of epoxy composites. Commercial grade bifunctional epoxy resin with phtalic anhydride as hardener and dimethylaniline as accelerator were used to prepare unidirectional composites with $60 \%$ vol. carbon fibers by 
impregnation and hot pressing procedure. The curing of the resin was carried out at $80{ }^{\circ} \mathrm{C}$ for 1 $\mathrm{h}$ and then post-cured at $140{ }^{\circ} \mathrm{C}$ for $2 \mathrm{~h}$, and the obtained bulk composites were used to characterize their thermal stability.

The ultrasound treatment (UST) of the continuous moving impregnated carbon fiber bundle was applied using ultrasound transducer (generator output frequency $20 \mathrm{kHz}$; power $225 \mathrm{~W}$ ), at total time of treatment of $2 \mathrm{~min}$.

In our previous paper we reported the results of DSC experiments carried out in order to determine the enthalpy of cure $(\Delta H)$ and $T_{\mathrm{g}}$ of the network formed under non-isothermal heating. To elucidate the role of ultrasound treatment on interface-sensitive properties of the composites, more detailed DSC experiments were performed on model systems and the obtained results are reported in this paper. Carbon fiber/epoxy resin model composites were subjected to isothermal DSC treatment at $120{ }^{\circ} \mathrm{C}$ for 1 hour in order to determine the reaction peak time, $t_{\mathrm{p}}$. Then the isothermal heating was followed by rapid cooling and a second heating run (dynamic regime, $10 \mathrm{~K}$ $\mathrm{min}^{-1}$ ) was made on the same sample in the range 20-200 ${ }^{\circ} \mathrm{C}$, and the final temperature was kept for $20 \mathrm{~min}$. After rapid cooling, third heating run after the second one (temperature range $25-200{ }^{\circ} \mathrm{C}$; heating rate $10 \mathrm{~K} \mathrm{~min}^{-1}$ ) was performed to evaluate possible further changes in $T_{\mathrm{g}}$ of the network as a result of post-curing effect. Differential scanning calorimetry (DSC) was performed with a PerkinElmer DSC-7 under nitrogen atmosphere. For the calibration of the instrument $\mathrm{Pb}$ and In were used. The enthalpy was calculated by

$$
\Delta H=(\mathrm{d} Q / \mathrm{d} t)_{\mathrm{p}=\text { const }} \beta^{-1} \mathrm{~d} T
$$

where $\beta=$ scanning rate; because $p=$ const, $\mathrm{d} Q /$ $\mathrm{d} t=\mathrm{d} H / \mathrm{d} t$.

Thermo-gravimetric analysis (TGA) was performed with a Perkin-Elmer Dyamond system under nitrogen atmosphere in the temperature range $30-700{ }^{\circ} \mathrm{C}\left(10 \mathrm{~K} \mathrm{~min}^{-1}\right)$. The mass of the samples used was $13.10-13.20 \mathrm{mg}$.

\section{RESULTS AND DISCUSSION}

In our previous paper [1] we investigated the influence of the ultrasonic treatment, applied during the impregnation of carbon fiber bundle by resin system, on interface sensitive properties of carbon fiber/epoxy resin composites. It was shown that, depending on the fiber surface chemistry, various degree of enhancement of ILSS, attributed to the formation of more homogeneous and dense network, could be achieved. ILSS was increased for all of investigated composites, although the most positive effect of the treatment was observed for epoxy sized carbon fiber composites (ILSS increased from $58 \mathrm{MPa}$ to $67 \mathrm{MPa}$ as a result of ultrasonic treatment) as compared to untreated and oxidized ones.

\section{DSC analysis}

The extremely large surface area of the fibers and the presence of different active groups on the surface of $\mathrm{CO}$ and $\mathrm{CE}$ fibers certainly influence the reaction mechanisms and the rates during the curing procedure $[9,10]$.

To further investigate the peculiarities of carbon fiber/epoxy resin systems exposed to ultrasonic treatment during the formation of the crosslinked polymer network, we performed isothermal DSC experiments on model composites. The results are presented in Table 1 .

T a b l e 1

DSC data on isothermal curing (carried out at $120^{\circ} \mathrm{C}$ ) of carbon fiber/epoxy resin composites: values in brackets are for the ultrasonic-treated systems

\begin{tabular}{cccc}
\hline \hline System & $\begin{array}{c}\text { Fiber content } \\
\text { vol } \%\end{array}$ & $\begin{array}{c}t_{\text {peak }} \\
\text { min }\end{array}$ & $\begin{array}{c}T_{\mathrm{g}} \\
{ }^{\circ} \mathrm{C}\end{array}$ \\
\hline Resin & - & $8.8(8.5)$ & $77.0(79.7)$ \\
CFE & 60 & $6.6(5.0)$ & $92.5(98.3)$ \\
CFO & 58 & $8.0(7.0)$ & $86.2(87.5)$ \\
CFU & 60 & $8.5(8.4)$ & $77.1(80.0)$ \\
\hline
\end{tabular}


The presence of carbon fibers, regardless the surface chemistry, influences the kinetics of cure and the process of network creation is obviously faster in all model composites $\left(t_{\text {peak }}=8.5\right.$ $-6.6 \mathrm{~min})$ compared to the pure resin $\left(t_{\text {peak }}=8.8\right.$ $\mathrm{min})$. The lowest value for the reaction time peak is seen for epoxy sized fibers. Similar behavior was earlier found for other carbon fiber composites [11]. However, more surprising is the effect of ultrasound treatment on the cure kinetics: while almost unchanged values for $t_{\text {peak }}$ of untreated carbon fibers (CFU) are determined for both conventional and US-treated system, significant reduction of $t_{\text {peak }}$ is reached for epoxy-sized carbon fibers containing composites. This acceleration is certainly partly due to the effect of ultrasound on the resin itself (as evidenced from insignificant reduction of $t_{\text {peak }}$ for the pure resin exposed to US before DSC isothermal curing), but mostly is a consequence of the increased molecular interactions at the interface of epoxy-sized fibers and the components of the resin system.

The enthalpy of cure, peak temperature, $T_{\mathrm{p}}$, and the resulting glass transition temperature obtained from the second and third DSC heating runs (see Figure 1), performed after isothermal curing and post curing at $200{ }^{\circ} \mathrm{C}$, are shown in Table 2. It should be mentioned that additional reaction effects in a solid state of the resin (after vitrification occur) are caused during the third heating run up to $200^{\circ} \mathrm{C}$.

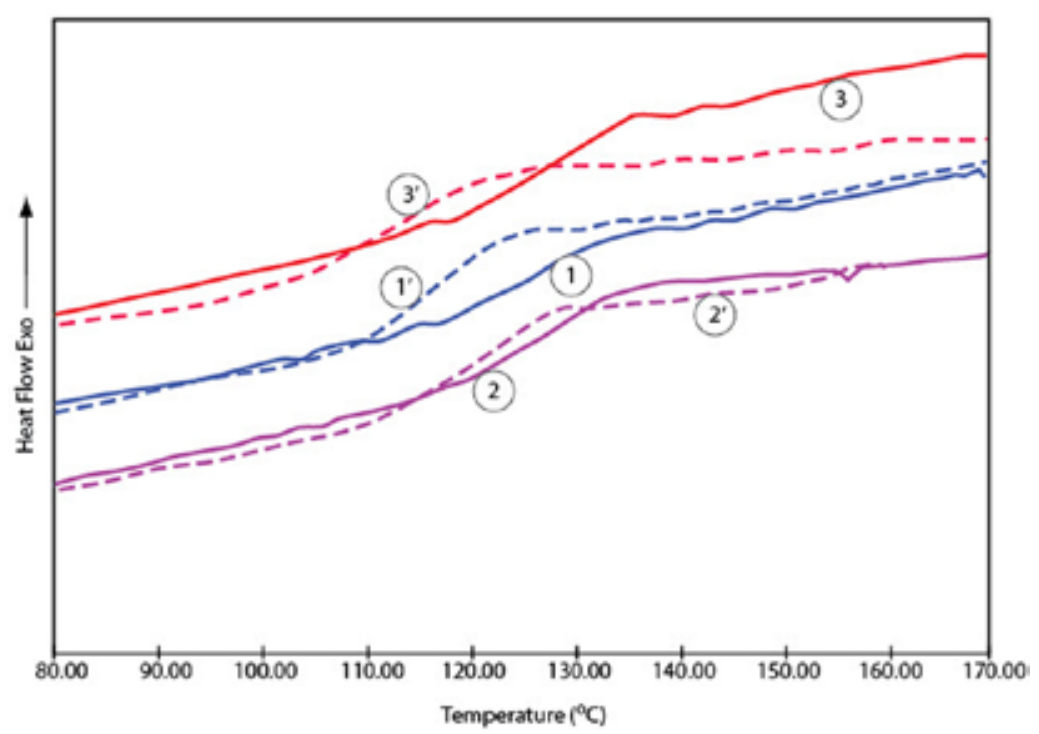

Fig. 1. DSC curves of US-treated carbon fiber/epoxy resin composites (II and III scan) obtained after isothermal curing at $120^{\circ} \mathrm{C}$ and post-curing $20 \mathrm{~min}$ at $200{ }^{\circ} \mathrm{C}$ : dot-lines correspond to second and full-lines - to third heating run.

$$
\text { 1, 1' - CFU, 2, 2' - CFE, 3, 3' - CFO }
$$

$\mathrm{T}$ a b 1 e 2

DSC analysis data obtained from the second and third heating runs performed after isothermal curing of CFE, CFO and CFU composites (values in brackets are for the ultrasonic-treated systems)

\begin{tabular}{cccccc}
\hline \hline \multirow{2}{*}{ System } & $\begin{array}{c}\text { DSC } \\
\text { run }\end{array}$ & $\Delta H / \mathrm{J} \mathrm{g}^{-1}$ & $T_{\mathrm{p}} /{ }^{\circ} \mathrm{C}$ & $T_{\mathrm{g}} /{ }^{\circ} \mathrm{C}$ & $\begin{array}{c}\Delta C_{\mathrm{p}} / \mathrm{J} \mathrm{g}^{-1} \\
\mathrm{grad}^{-1}\end{array}$ \\
\hline \multirow{2}{*}{$\mathrm{CFE}$} & II & -1.98 & $237.0(237.2)$ & $119.0(119.0)$ & 0.13 \\
& III & -0.49 & $230.2(230.0)$ & $\mathbf{1 2 7 . 5}(\mathbf{1 2 7 . 0})$ & 0.11 \\
& II & -2.10 & $230.4(230.0)$ & $113.0(112.1)$ & 0.15 \\
& III & -0.52 & $229.0(230.0)$ & $\mathbf{1 2 5 . 3 ( 1 2 6 . 0 )}$ & 0.12 \\
& II & -2.20 & $228.6(225.0)$ & $113.2(111.0)$ & 0.14 \\
& III & -0.45 & $229.9(230.9)$ & $\mathbf{1 2 4 . 1 ( 1 2 2 . 5 )}$ & 0.12 \\
\hline \hline
\end{tabular}


Obviously, after post-curing the crosslinking reaction between the active groups of the resin and/or the surface groups of the fibers proceeds further (second and third run), resulting in an increased glass transition temperature, compared to those determined after the isothermal curing at $120^{\circ} \mathrm{C}$ (see Table 1). The values for $T_{\mathrm{g}}$ of the analyzed composites after these consecutive thermal treatment in the course of DSC scans are still below the $T_{\mathrm{g}}$ of bulk composites $\left(136-143{ }^{\circ} \mathrm{C}\right)$ produced by hot pressing at $80{ }^{\circ} \mathrm{C}$ for 1 hour and then post-cured at 140 ${ }^{\circ} \mathrm{C}$ for 2 hours [1]. Similar results are obtained for both epoxy-sized and oxidized systems, but also for the composites with untreated carbon fibers, CFU. Somewhat lower heat of cure for the epoxy-sized fibers containing composite compared to the CFE composite is proving that a higher initial degree of crosslinking is already reached in the course of previous thermal treatment.

These results clearly confirm our earlier findings on the influence of ultrasound treatment applied during the preparation of the carbon fiber/epoxy resin systems. Although the ultrasound treatment can significantly decrease the viscosity and surface tension of the resin system, thus increasing the wettability, and also the oxygen content of the fiber surface due to the cavitation effects [12], these phenomena are not seen in our work, at least not under the conditions the US-treatment is applied in our experiments [1].

DSC experiments performed with untreated and US-treated composites have pointed out that the enhanced fiber/matrix bonding strength, and as a consequence - increased interlaminar shear strength (ILSS), is a result of the changes that happen at very early stage of curing process due to partial dissolution of the carbon fiber epoxy-sizing into the matrix polymer thus favoring the cure reactions in the interphase zone.

\section{TG-analysis}

It is well known that ILSS is dominated by the properties of the matrix and the fiber-matrix interphase, and that the degradation of both the matrix and the interphase is responsible for decrease in ILSS during environmental and/or thermal ageing of the composites. To evaluate the effects of US-treatment more in detail, thermal degradation of CFE and CFO composites is compared and the results are shown on Figure 2 and Table 3.

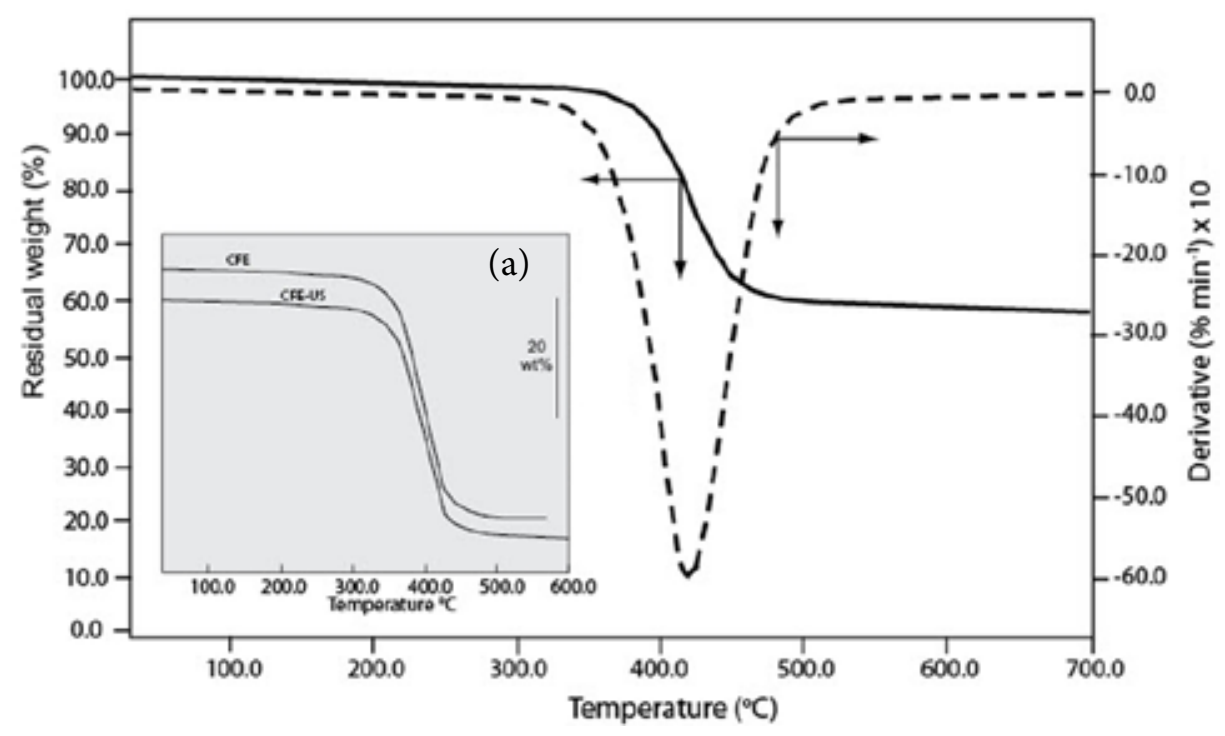

Fig. 2. TGA (full-line) and DTG (dot-line) curves of bulk CFE composites produced via conventional hot pressing process. TG-traces of CFE and CFE-US treated bulk composites (a). 
$\mathrm{T}$ a b 1 e 3

Thermal degradation characteristics of carbon fiber/epoxy composites determined by TGA/DTG: (values in brackets are for the ultrasonic-treated systems)

\begin{tabular}{|c|c|c|c|c|c|c|}
\hline Composite & $\begin{array}{l}\text { Weight loss at } \\
750^{\circ} \mathrm{C} / \%\end{array}$ & $\begin{array}{c}T_{1} /{ }^{\circ} \mathrm{C} \\
\text { at weight loss } \\
\text { of } 1 \%\end{array}$ & $\begin{array}{c}T_{5} /{ }^{\circ} \mathrm{C} \\
\text { at weight loss } \\
\text { of } 5 \%\end{array}$ & $\begin{array}{c}T_{10} /{ }^{\circ} \mathrm{C} \\
\text { at weight loss } \\
\text { of } 10 \%\end{array}$ & $T_{\text {DTG }} /{ }^{\circ} C^{*}$ & $\begin{array}{l}\text { Weight loss } \\
\text { rate at } T_{\mathrm{DTG}} \\
\quad \% \mathrm{~min}^{-1}\end{array}$ \\
\hline CFE & $39.6(40.0)$ & $242.5(\mathbf{2 5 5 . 7})$ & 348.0 (350.2) & $370.0(371.0)$ & 397.4 (402.9) & $5.01(4.80)$ \\
\hline $\mathrm{CFO}$ & $39.3(38.5)$ & $248.6(\mathbf{2 4 7 . 9})$ & $349.6(\mathbf{3 5 0 . 7})$ & $367.0(367.0)$ & $397.9(400.3)$ & $5.20(5.17)$ \\
\hline
\end{tabular}

It can be seen from Figure 2, that the thermal decomposition of the epoxy resin in CFE composites, untreated and US-treated, proceeds via identical one-step mechanism. Similar behavior is also seen for CFO composites. However, the stronger interfacial bond of CFE composites produced by US-assisted process has obviously resulted in delay of thermal degradation: temperature of $1 \%$ and $5 \%$ weight loss is shifted to higher values (Table 3, Figure 3).

All other parameters of thermal degradation, as it was expected, were similar and (taking into account negligible difference in composites fiber content - weight loss at $750{ }^{\circ} \mathrm{C}$ is in the range $38.5-40 \% \mathrm{wt}$ ) in the range of experimental error.

These results are in accordance with our earlier findings that at an early stage of cure (30 $\mathrm{min}$ ) the presence of fibers with different surface chemistry influences the crosslink density of the network, due to the possible catalytic activity of certain functional groups at the surface and also to the phenomenon of preferable absorption of some components of the epoxy resin [13]. Higher network density created by US-treatment at the vicinity of epoxy-sized fibers (CFE) influences not only interlaminar strength of the composites, but has also affected their thermal degradation behavior.

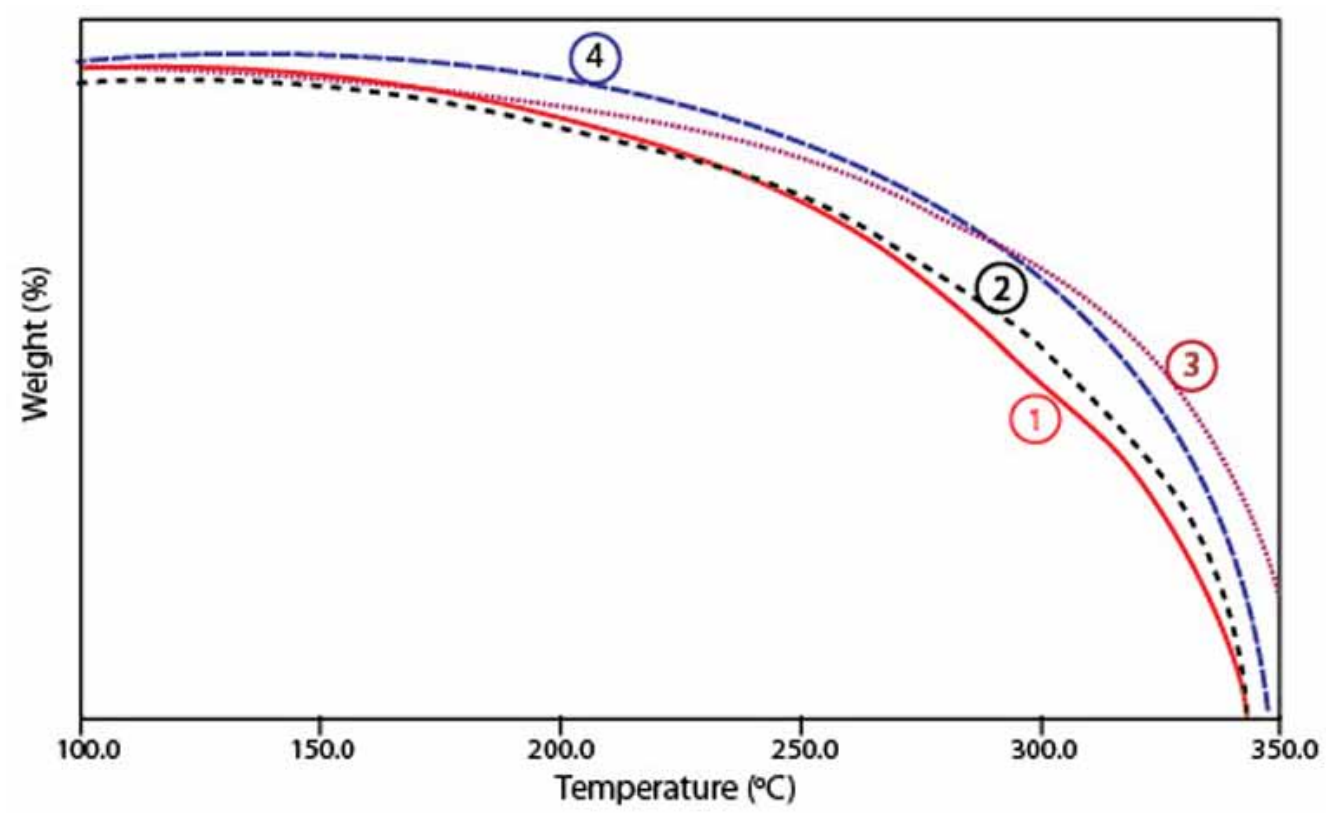

Fig. 3. Thermal degradation curves of CFO $(1,2)$ and CFE $(3,4)$ composites produced via conventional $(1,3)$ and US-assisted process $(2,4)$ in temperature range $100-350^{\circ} \mathrm{C}$. 


\section{CONCLUSION}

Ultrasonic treatment applied during the impregnation of carbon fibers by epoxy resin has resulted in acceleration of the reaction rate, as revealed by significant reduction of $t_{\text {peak }}$ in isothermal curing of epoxy-sized carbon fiber composites. The crosslinking reaction between the active groups of the resin and/or the surface groups of the fibers proceeds further in solid state, after the vitrification occur, followed by changes in $T_{\mathrm{g}}$ of the network. This effect is due to insufficient degree of crosslinking reached in the phase of thermal treatment, and is predominantly seen for $\mathrm{CFU}$ and CFO-composites, pointing out that the ultrasonic treatment is most effective in epoxy-sized carbon fiber system. The stronger interfacial bond in CFE composites, favored by US-treatment, has also generated differences in thermal behavior of the composites during their degradation: at earlier stage of epoxy matrix decomposition (up to 260 ${ }^{\circ} \mathrm{C}$ ) temperature of $1 \%$ weight loss is shifted from 242.5 to $255.7^{\circ} \mathrm{C}$.

Acknowledgements. The authors are grateful for the support of this work by EUREKA Program within the EUREKA DE_AMATECH project, co-financed by the Ministry of Higher Education, Science and Technology of Republic of Slovenia and Ministry for Education and Science of Republic of Macedonia.

\section{REFERENCES}

[1] G. Bopgoeva-Gaceva, N. Heraković, D. Dimes$\mathrm{ki}$, V. Stefov, Ultrasound assisted process for enhanced interlaminar shear strength of carbon fiber/epoxy resin composites, Maced. J. Chem. Chem. Eng. 29, 149-155 (2010).
[2] Y.T. Didenko, W.B. McNamara, K.S. Suslick, Hot spot conditions during cavitation in water, J. Am. Chem. Soc. 121, 5817-5818 (1999).

[3] W. Lauterborn, Handbook of Acoustics, In: Crocker MJ (ed.), 1998, pp. 235-242.

[4] J. Suave, L.A.F. Coelho, S.C. Amico, S.H. Pezzin, Effect of sonication on thermo-mechanical properties of epoxy nanocomposites with carboxyulated-SWNT, Materials Sci. Eng. A 509, 57-62 (2009).

[5] W. Brockmann, P.L. Geiss, J. Klingen, K.B. Schroder, B. Mikhail, Adhesive Bonding: Materials, Applications and Technology, Weinheim, Wiley-VCH, 2009.

[6] J. Holtmannspotter, J.V. Czarnecki, H.J. Gudladt, The use of power ultrasound energy to support interface formation for structural adhesive bonding, Int. J. Adhesion \& Adhesives 30, 130-138 (2010).

[7] L. Liu, Y.D. Huang, Z.Q. Zhang, Z.X. Jiang, L.N. $\mathrm{Wu}$, Ultrasonic treatment of aramid fiber surface and its effect on the interface of aramid/epoxy composites, Appl. Surface Sci. 254, 2594-2599 (2008)

[8] G. Bogoeva-Gaceva, E. Mader, L. Haüssler, K. Sahre, Parameters affecting the interface properties in carbon fiber/epoxy systems, Composites 26, 103-107 (1995).

[9] N. Dilsize, J.P. Wightman, Effect of acid-base properties of unsized and sized carbon fibers on fiber epoxy matrix adhesion, J. Colloids and Surfaces 164, 325-336 (2000).

[10] G. Bogoeva-Gaceva, E. Mäder, L. Haüssler, A. Dekanski, Characterization of the surface and interphase of plasma-treated HM carbon fibers, Composites A 28 A, 445-452 (1997).

[11] Y.D. Huang, L. Liu, J.H. Qui, L. Shao, Influence of ultrasonic treatment on the characteristics of epoxy resin and the interfacial property of its carbon fiber composites, Comp. Sci. Technol. 62, 2153-2159 (2002).

[12] G. Bogoeva-Gaceva, E. Mader, L. Haüssler, K. Sahre, Parameters affecting the interface properties in carbon fiber/epoxy systems, Composites 26, 103-107 (1995). 
